Meta

Journal des traducteurs

Translators' Journal

\title{
Translations of Sovietisms: A Comparative Case Study of English Translations of Bulgakov's The Master and Margarita
}

\section{Natalia Kaloh Vid}

Volume 62, numéro 1, avril 2017

URI : https://id.erudit.org/iderudit/1040472ar

DOI : https://doi.org/10.7202/1040472ar

Aller au sommaire du numéro

\section{Éditeur(s)}

Les Presses de l’Université de Montréal

\section{ISSN}

0026-0452 (imprimé)

1492-1421 (numérique)

Découvrir la revue

\section{Citer cet article}

Kaloh Vid, N. (2017). Translations of Sovietisms: A Comparative Case Study of English Translations of Bulgakov's The Master and Margarita. Meta, 62(1), 178-200. https://doi.org/10.7202/1040472ar

\section{Résumé de l'article}

Le roman Le Maître et Marguerite de Bulgakov (1966-1967), roman très complexe à plusieurs niveaux, est un défi pour tout traducteur. Cet ouvrage de Boulgakov ayant été traduit en anglais à sept reprises (deux fois par le même traducteur, Glenny) - les deux premières traductions la même année, 1967, et la dernière en 2008 - il permet un examen unique des changements opérés par la traduction, non seulement dans une perspective synchronique mais aussi diachronique. L'accent est mis sur la traduction des realia historiques appelés " soviétismes » (les éléments caractéristiques de l'URSS des années 1930) et des mots-valises non standards de la " Russie soviétique ». La langue de Bulgakov est saturée de vocabulaire se référant à divers éléments culturels et sociopolitiques de la réalité soviétique. Les soviétismes apparaissent à différents niveaux (lexical, syntaxique, stylistique et rhétorique) et doivent être soigneusement traduits comme une caractéristique importante du style de l'auteur. Une « naturalisation » complète des soviétismes peut conduire à une perte de sens connotatif, qui est essentiel pour comprendre le contexte, alors qu'une " étrangéisation " de ces termes, probablement inconnus des lecteurs occidentaux, peut perturber la fluidité de la lecture. Le but de l'analyse est donc d'illustrer l'utilisation des stratégies de naturalisation et d'étrangéisation en traduction et d'évaluer ces choix, étant donné que le public cible anglophone ne connaît probablement pas la plupart de ces termes. L'analyse des cas se base sur la théorie de l'étrangéisation et de la domestication, ainsi que sur les taxonomies proposées par Vinay et Darbelnet (1958/1989), Vlahov et Florin (1995), et Aixelá (1996). 


\title{
Translations of Sovietisms: A Comparative Case Study of English Translations of Bulgakov's The Master and Margarita
}

\author{
NATALIA KALOH VID \\ Faculty of Arts University of Maribor, Maribor, Slovenia \\ natalia.vid@siol.net
}

\section{RÉSUMÉ}

Le roman Le Maître et Marguerite de Bulgakov (1966-1967), roman très complexe à plusieurs niveaux, est un défi pour tout traducteur. Cet ouvrage de Boulgakov ayant été traduit en anglais à sept reprises (deux fois par le même traducteur, Glenny) - les deux premières traductions la même année, 1967, et la dernière en 2008 - il permet un examen unique des changements opérés par la traduction, non seulement dans une perspective synchronique mais aussi diachronique. L'accent est mis sur la traduction des realia historiques appelés «soviétismes» (les éléments caractéristiques de l'URSS des années 1930) et des mots-valises non standards de la «Russie soviétique». La langue de Bulgakov est saturée de vocabulaire se référant à divers éléments culturels et sociopolitiques de la réalité soviétique. Les soviétismes apparaissent à différents niveaux (lexical, syntaxique, stylistique et rhétorique) et doivent être soigneusement traduits comme une caractéristique importante du style de l'auteur. Une «naturalisation» complète des soviétismes peut conduire à une perte de sens connotatif, qui est essentiel pour comprendre le contexte, alors qu'une «étrangéisation » de ces termes, probablement inconnus des lecteurs occidentaux, peut perturber la fluidité de la lecture. Le but de l'analyse est donc d'illustrer l'utilisation des stratégies de naturalisation et d'étrangéisation en traduction et d'évaluer ces choix, étant donné que le public cible anglophone ne connaît probablement pas la plupart de ces termes. L'analyse des cas se base sur la théorie de l'étrangéisation et de la domestication, ainsi que sur les taxonomies proposées par Vinay et Darbelnet (1958/1989), Vlahov et Florin (1995), et Aixelá (1996).

\begin{abstract}
Bulgakov's novel The Master and Margarita (1966-1967), a highly complex and multilevelled narrative, is a challenge for any translator. Because Bulgakov's narrative has been translated into English seven times (twice by the same translator, Glenny), with the first two translations published in the same year, 1967, and the latest in 2008, the novel offers a unique insight into the analysis of translation shifts, not merely from a synchronic, but also from a diachronic perspective. The emphasis here is on the translation of historical realia, referred to as Sovietisms, and pertaining to items characteristic of Soviet discourse of the 1930s, word-formations of the non-standard "Soviet Russian." Bulgakov's language is sated with Soviet vocabulary which refers to various cultural and socio-political elements of Soviet reality. Sovietisms occur at various levels (lexical, syntactical, stylistic and rhetorical) and should be carefully translated as a significant characteristic of Bulgakov's style. A complete domestication of Sovietisms may lead to a loss of a connotative meaning essential for understanding the context, while a foreignization of these terms which are most likely unknown to Western readers may disturb the fluency of reading. The purpose of the analysis, thus, is to illustrate the use of domesticating/foreignizing strategies employed by the translators and to assess the translation choices, considering that the target audience of English-speaking readers are most likely completely unfamiliar with most terms. The analysis employs theory on foreignizing and domesticating principles,
\end{abstract}


as well as taxonomies suggested by Vinay and Darbelnet (1958/1989), Vlakhov and Florin (1980) and Aixelá (1996) as the grounds for the case study.

\section{RESUMEN}

La novela de Bulgákov, El Maestro y Margarita (1966-1967), es una narración multi-nivel de gran complejidad, un desafío para cualquier traductor. Debido a que la narrativa de Bulgákov ha sido traducida al inglés siete veces (dos de ellas por el mismo traductor, Glenny), siendo publicadas las dos primeras traducciones en el mismo año, 1967, y la última en el 2008, la novela ofrece una visión única respecto al análisis de los cambios de traducción, no sólo de forma sincrónica, sino también desde una perspectiva diacrónica. El énfasis recae aquí en la traducción de los realia históricos, considerados como sovietismos, pertenecientes a objetos característicos del discurso soviético de los años 1930, formaciones de palabras a partir del "ruso soviético" no estandarizado. El lenguaje de Bulgákov está lleno de vocabulario soviético relacionado con varios elementos culturales y sociopolíticos de la realidad soviética. Los sovietismos se dan en diferentes niveles (léxico, sintáctico, estilístico y retórico) y deberían ser traducidos cautelosamente como característica significativa del estilo de Bulgákov. Una completa domesticación de los sovietismos podría llevar a una pérdida connotativa del significado esencial necesario para entender el contexto, mientras que una extranjerización de los términos, términos que probablemente sean desconocidos para los lectores occidentales, podría alterar la fluidez de la lectura. El propósito del presente análisis es, por tanto, ilustrar el uso de las estrategias de domesticación/extranjerización empleadas por los traductores y acceder a las posibles formas de traducir, considerando que el mercado objetivo angloparlante no esté familiarizado con la mayoría de los términos. El análisis emplea una teoría basada en los principios de extranjerización y domesticación, así como taxonomías sugeridas por Vinay y Darbelnet (19581989). Vlakhov y Florin (1980) y Aixelá (1996) como bases del presente estudio.

\section{MOT-CLES/ KEY WORDS/PALABRAS CLAVE}

Bulgakov, discours soviétique, culture, stratégies de traduction

Bulgakov, soviet discourse, culture, translation strategies

Bulgákov, discurso soviético, cultura, estrategias de traducción

\section{Introduction}

This comparative corpus analysis is based on six English translations of Bulgakov's major prose work The Master and Margarita by Ginsburg (1957/1995), ${ }^{1}$ Glenny (1967 and later republished in 1971/1974/1985/1988/1989/1992/2003/2014); ${ }^{2}$ Burgin and O'Connor (1995); ${ }^{3}$ Pevear and Volokhonsky (first published in 1997 and later republished in 2000/ 2001/2004/2006/2007); ${ }^{4}$ Karpelson (2006), ${ }^{5}$ and Aplin (2008). ${ }^{6}$

It focuses on the translation of Sovietisms, culturally-, historically- and sociallyspecific terms from the Soviet speech of the 1930s brought into the Russian language through the discourse of revolution and the communist regime to describe different aspects of Soviet life (professions, institutions, propagandistic slogans, etc.). Drawing on existing theories in the translation field, this paper seeks to develop a conceptual framework suited specifically to the analysis of translation of Sovietisms which may have wider applicability when analyzing the existing translations and especially when re-translating into English Soviet classics by Zoshchenko, Sholokhov, Bunin, Pasternak, Solzhenitsyn, Aitmatov and others in which Sovietisms represent the crucial realities of the Soviet socio-cultural development and should be rendered adequately. 
The reason I have chosen The Master and Margarita as corpus is, firstly, because there are only a few works of Russian literature which have been re-translated into English so many times and which thus offer extensive material for a comparative case study, while illustrating how or whether literary translation shifts are changing over time. Considering the uniqueness of this material, I found it surprising that no comparative research of all six English translations (to my knowledge) from any aspect has been done so far. Secondly, my intention was to draw attention to different choices used when translating Sovietisms, along with what these choices entail for the reader's impression and perception of the narrative. Finally, little scholarly attention has been paid to the translation of Sovietisms in Bulgakov's prose, although they present one of the main challenges for any translator, since any translator should be able to decode the cultural and political subtext expressed by means of a semiotic code.

As distinctive signs of Soviet times, Sovietisms have important functions in Bulgakov's narrative; they illustrate how the literary Russian language was changed and manipulated by the authorities, how it became trapped in revolutionary terminology, and how it was reduced to propagandistic discourse which expressed above all fear and paranoia. Sovietisms have no equivalents in English and are often incomprehensible without additional explanation of the political and ideological situation in the former Soviet Union. Without the translator's help, the unprepared reader may get lost in the labyrinth of clippings, blendings, phraseological expressions, puns, allusions, and other linguistic features of Bulgakov's style. As with any other culturally-specific terms, Sovietisms carry important though implicit information, and simplification or neutralization of these national, cultural and social components would significantly change the interpretive coordinates. No translation of The Master and Margarita can be considered culturally successful unless proper attention is paid to the translation of Sovietisms, and it is the task of the translator to make appropriate decisions on how she/he will compensate linguistically for the target reader's lack of background knowledge. As in the case of other culturally specific elements, the question arises whether translators of Bulgakov's narrative need to follow foreignizing principles by keeping Sovietisms intact, or to substitute them with cultural equivalents, thus domesticating the translation and making it more fluent.

The current analysis is carried out with the methodological help of Vlakhov and Florin's and Pikhurova's categorizations of Sovietisms, along with Vinay and Darbelnet's and Aixelá's methodology for analysis of translation shifts. It focuses on the use of foreignizing and domesticating choices applied by Bulgakov's translators. Each translation choice will be evaluated on the basis of rendering a denotative and a connotative meaning, in consideration of the target audience of English-speaking readers who are completely unfamiliar with most terms.

As it is impossible to analyze all categories of Sovietisms used in Bulgakov's narrative and their translations within one study, the main part of the study consists of a comparative analysis of a few illustrative examples, thus offering a basis for further research into Sovietisms in English translations of Bulgakov's works. 


\section{Theoretical background: foreignizing and domesticating}

One debate in translation studies that continues to reverberate is whether to use a strategy of domestication or a strategy of foreignization. The translator whose name is most associated with this debate nowadays, Lawrence Venuti, sees the dominance of fluency in British and American translational tradition as proof that domestication is a vital method for successful translation practices in the contemporary Englishspeaking world. In the first chapter of his book The Translator's Invisibility, Venuti (1995: 5) criticizes "fluent translation," as being "immediately recognizable and intelligible, 'familiarised,' domesticated, not 'disconcerting[ly]' foreign, capable of giving the reader unobstructed 'access to great thoughts,' to what is 'present in the original."' Coming down clearly on the side of a foreignizing method, Venuti (2006: 547) regards the use of a domesticating strategy as "ethnocentric violence" which is very often put in the service of an "imperialist appropriation of foreign cultures for domestic agendas, cultural, economic, political."

Following Venuti's ideas, advocates of the foreignizing method (e.g. Oittinen 2006) believe that any text should be foreignized, and they name different forms and strategies aimed at "helping" a translation to keep the spirit of the foreign and consequently to enable the reader to experience the foreign culture.

Though these ideas serve as a useful reminder to translators to be more selfconscious, open to new tendencies, and independent, it is problematic to state that a translation's quality depends entirely on providing an 'alien' reading experience. Thus, Lederer draws upon a principle feature of any translation as a communicative act and concludes that,

For a translation to be understood by the person who depends on it, translators must constantly remind themselves that translation is simply a particular type of communication. What happens when we have something to say? We express it intelligibly in forms accepted by all. Sense is individual but forms are social. (Lederer 2003: 58)

Lederer's interpretive model of translation theory exposes more the meaning of the message than the form, as "the transfer is supposedly through sense and not words" (2003: 13). Hence, the information is the most vital part of the translation and should be transferred by all means, regardless of which principle a translator decides to embrace. Although what Catford refers to as structural shifts - mainly involving changes in grammatical structure (Catford 1965: 75-82) - are inevitable, the integrity of whatever message the author is trying to convey must nonetheless remain in the target text.

The proper decisions for foreignization or domestication are usually culturally variable, historically contingent, and dependent on various other factors, such as the language. Thus, pondering the question of "foreign-soundingness" in translation, Bellos states that "selective or decorative foreignism is available only in translation between languages with an established relationship" (2011: 45), for instance, English and French. The established relationship between French and English gives a chance to the translator to foreignize the target text without disturbing the fluency of reading, as "the project of writing translations that preserve in the way they sound some trace of the work's 'authentic foreignness' is really applicable only when the original is not very foreign at all" (Bellos 2011: 47). 
Similarly, Eco gives examples of right choices for domestication and foreignization by examining situations when one of the two strategies used decreased the readability of the translation by either introducing an incomprehensible cultural reference or destroying the historical consistency of the text (Eco 2001: 22-24).

Andrews and Maksimova also avoid strict criticism of either method. They distinguish between ST preference - which means that "if the translator's ultimate goal is to preserve as much as possible from the ST, then the resulting TT is generally referred to as literal" - and TT preference - if the "translator's ultimate goal is to produce a TT that reads as if it were written originally in the TL for the culture and speakers of the TL, then we have to do with what is often referred to as free translation" (2010: 10-11). Neither of the methods is universal, as the authors conclude that "even at the lexical and discourse levels, the degrees of freedom are greatly restricted and vary from utterance to utterance" (Andrews and Maksimova 2010: 11). Thus, any TT would be restricted in a similar fashion, with "greater restrictions at the phonemic and grammatical levels, and lesser restrictions at the lexical and discourse levels" (Andrews and Maksimova 2010: 11).

Hervey and Higgins (2002: 18-25) also articulate the philosophy of minimizing difference as a central goal of translation, regardless of foreignizing/domesticating strategies applied. As every translation involves a certain degree of loss in meaning, the translator's task is not to seek the perfect or ideal translation but to reduce the translation loss. To achieve this aim, the translator will have to decide "which of the relevant features in the ST it is most important to preserve, and which can most legitimately be sacrificed in preserving them" (Hervey and Higgins 2002: 25).

Though providing a detailed assessment of each strategy's advantages and disadvantages is beyond the limits of the current analysis, we can sum up the foreignizing method as being one that helps the translator to faithfully convey the message of the original writer, while offering the target readership a chance to enjoy a different cultural atmosphere, as well as new vocabulary and terms within the target language. The process of borrowing among languages enables this.

In contrast, advocates of domestication argue that domesticating foreign literature offers a more pleasant and undisturbed reading experience, preserves the source language's norms, and keeps them intact from any alien interference or exotic additions. Domestication grants the translator more freedom to manipulate the source text and, finally, according to Yang (2010: 77), "alien cultural images and linguistic features may cause information overload to the reader." Advocates of domestication also claim that foreignization does not absorb readers from all levels, as foreign knowledge that appeals to the elite and educated strata might not appeal to "grassroots," as "domesticating translation is easier for the readers to understand and accept" (Yang 2010: 79).

Considering these aims, the question of the possibility of keeping the trace of foreignness in translations should be rephrased as: is it possible to use foreignizing strategies in a translation within a particular language pair, yet still produce a "fluent" translation in the positive sense? Can both principles be successfully employed, thus offering readers sufficient information about a foreign culture without making the reading process too challenging? As we shall see, translations of The Master and Margarita offer a case study for all three possibilities: domestication, foreignization, and the combination of both. 


\section{Methodology: definition and translation of Sovietisms}

Before we move on to the analysis of Sovietisms in English translations of Bulgakov's novel, it is necessary to define what a Sovietism is. As different terminology is used when defining the term, I will use the seminal works (in Russian) by Vlakhov and Florin (1980) on translating realia, specifically as presented in the chapter entirely devoted to Sovietisms and the ways of translating them. In Vlakhov and Florin's methodological research Sovietisms are rendered as a sub-category of "realia," "words or word-formations which name subjects, facts and objects characteristic of life, a mode of life, culture, social development of one nation and unclear or completely unknown to another, which express a national and/or a historical "kolorit" (Vlakhov and Florin 1980: 47; all translations are made by the author). The term colouring [колорит] often used by the authors refers to the sum of specific features of the epoch, the people and the place. When specifying Sovietisms as "lexical marks of the epoch" (Vlakhov and Florin 1980: 45), Vlakhov and Florin state that, unlike other types of realia, Sovietisms "apart from the connotative meaning and the national kolorit of common realia, also have their own, social kolorit specific only for the Soviet regime" (Vlakhov and Florin 1980: 148). Consequently, a translation of any Sovietism should render "three connotative levels: national, historical and social"10 (Vlakhov and Florin 1980: 143), while the translator should keep in mind that the information contained in a Sovietism is clear only to Soviet readers, or to readers from other socialist countries who experienced life under a socialist regime. The same information is usually confusing for readers "out of our camp"11 (Vlakhov and Florin 1980: 143).

Vlakhov and Florin divided Sovietisms into three categories:

1) Sovietism-realia which were characteristic of the Soviet Union (e.g. совхоз/stateowned collective farm, неотложка/emergency car, ЖЭК/a house committee, целинник/somebody working on the Virgin lands during the "Virgin Lands Campaign," стахановец/an established rewarded worker) and should always be translated considering the absence of equivalents in the target readers' culture but also considering the common fact that readers from Socialist countries in any case have a more extensive knowledge about the USSR in comparison with readers from Western countries;

2) Regional Sovietisms which usually do not differ from national terms in any socialist country and are usually translated to the languages of the socialist countries with corresponding equivalents by methods of a transliteration and a calque;

3) International Sovietisms (Совет, спутник, большевик) which are so well-known that they do not require additional explanations and are translated by a transcription.

(Vlakhov and Florin 1980: 144-145) ${ }^{12}$

While translation strategies differ, most Sovietisms in Bulgakov's The Master and Margarita belong to Sovietisms-realia. For a more illustrative structuring of the examples, another categorization is used, namely the one by Pikhurova, who divided Sovietisms into three groups:

1) Lexical: words and expressions which occurred or were coined in the years between the 1920s and the 1970s to describe elements of Soviet reality (бракодел, обезличка,подкулачник);

2) Semantic: previously existing words which acquired an entirely new meaning in a Soviet reality (вредитель, достать); 
3) Connotative: words with additional meanings attached (авангард, гнёт). ${ }^{13}$

(Pikhurova 2005: 8-9)

When speaking about translation strategies for translating Sovietisms Vlakhov and Florin agree with Shveitser, who stated that:

In the texts written for professionals and readers familiar with Soviet realities, translators usually use a transliteration and a calque (e.g. агитпункт-agitpunkt, дружинникиdruzhinniki, область-oblast), while in texts which address a broader audience, we find explanatory translations (e.g. agitpunkt-vote re-education citizen court, druzhinnikivolunteer patrols), and transliterations and calques are normally accompanied by comments $^{14}$ (Shveitser 1973: 251)

Though it is possible in most cases to transfer the denotative meaning of Sovietisms fairly closely, Vlakhov and Florin state that nothing guarantees that the connotative meaning will also be fully transferred, and the terms may be substituted with "a word or a formation with a zero connotation" (1980: 89). ${ }^{15}$ While in several cases a connotative meaning is partly transferred, not all connotations attached to Sovietisms can be rendered within the text, and comments are usually required. These are provided in four of the translations: Pevear and Volokhonsky's, Burgin and O'Connor's, Karpleson's and Aplin's.

From a methodological point of view, it is also important to refer to the choice of translation taxonomy, as there are numerous traditional typologies that could be applied to the analysis and evaluation of translation shifts. The question that naturally arises here is: which one is to be used? It is important to state that the original and all six translations have been read and analysed in a contrastive, linguistically-oriented manner with a focus on lexical shifts that occur only on a micro-textual level.

As terminology to define translation strategies for culture-specific items is not unified and the number and specifics vary from one source to another, I will use Vinay and Darbelnet's (1958/1989) taxonomy, which, in my opinion, should still be considered one of the most helpful models to classify the principal linguistic operations that translators perform. It is clearly structured and though it may seem a bit dated, I will illustrate that it has been successfully adopted by other scholars of translation who use similar distinctions and sometimes also similar terms. Vinay and Darbelnet proposed seven methods that are sufficient for the analysis of the translation shift at the micro-textual level and cover most of the parameters, methods or strategies suggested in subsequent studies, namely: (a) borrowing; (b) calque; (c) literal translation as foreignizing methods, (d) transposition; (e) modulation; (f) adaptation, and (g) equivalence as domesticating.

It shows similarities with Chesterman's classification (1997), which distinguishes between comprehension strategies (for understanding and analyzing the source text) and production strategies (for the production of the target text). From a linguistic perspective, Chesterman divides production strategies into syntactic/grammatical, semantic and pragmatic strategies, with each category containing ten techniques. Syntactic strategies involve purely syntactic changes, manipulate form, and include such techniques as calque, transposition, and sentence structure change. Semantic strategies mainly pertain to changes concerning lexical semantics. Pragmatic strategies have to do with the selection of information in the target text, and often involve syntactic and/or semantic changes as well. Though Chesterman's classification is 
more detailed than Vinay and Darbelnet's, it covers various fields not relevant to the current study, while some translation strategies could not be applied for the corpus of culturally-specific realia, e.g., sentence word order, phrase and clause structure change, converses, abstraction change, coherence change, interpersonal change, etc. At the same time, strategies of calquing, literal translation, transposition and cultural filtering correspond to those suggested by Vinay and Darbelnet.

A more detailed model was suggested by Van Leuven-Zwart (1989), who also took as a point of departure some of the categories proposed by Vinay and Darbelnet and Levý and applied them to the descriptive analysis of a translation, attempting both to systematize comparison and to build in a discourse framework above the sentence level. The three main categories Leuven-Zwart suggested are modulation, modification and mutation. Though detailed, this taxonomy is not based on a clear distinction between domesticating/foreignizing strategies, which serve as the most important theoretical background for the current analysis.

Baker's (1992: 26-42) comparative typology: (a) translation using a more general word; (b) translation using a more neutral/ less expressive word; (c) translation using a cultural substitution; (d) translation using a loan word or loan word plus explanation; (e) translation by paraphrase using a related word; (f) translation by paraphrase using unrelated words; (g) translation by omission; (h) translation by illustration, is often used by professional translators, yet it does not encompass such categories as calquing or literal translations, which are essential for the current analysis, while strategies of the use of a loan-word and cultural substitution are similar to Vinay and Darbelnet's strategies of borrowing and adaptation. In addition, there were no examples of translation by paraphrase, use of a more general word, use of a less expressive word, omission or illustration in the examples chosen for the current analysis.

Various functionalist translation taxonomies allow the same text to be translated in different ways, depending on the purpose of the target text and the given commission, hence, depending on the "initiator's needs" (Nord 2005: 10). The differing strategies and solutions that can be seen may therefore be due to different purposes of the translations. The strategy adopted by Nord consists of decentralizing the notion of textual type, giving greater emphasis to the notion of textual genres and sketching a solution to prototypes in this level. Yet the main assumption of the current analysis is to analyse shifts that occur on a micro-textual level, which vaguely corresponds to Nord's intra-textual factors. The purpose of the current analysis was, thus, not to analyze the content of the text, the overall idea, the ideas explicitly presented or the ideas implied within, while Nord's parameters covering the structural linguistic properties of the text, composition, lexis and sentence structure, seem to be too broad to be applied to an analysis of culturally-specific items. Accordingly, extra-textual parameters as well as the question of possible purposes of various translations of Bulgakov's narrative would be a topic for a different research study.

As such, Vinay and Darbelnet's taxonomy seems to be relevant for the current analysis, as the suggested strategies, which partly correspond to subsequent taxonomies, suffice for the evaluation of the selected translation choices. Hence, it will be combined with a method of transliteration, which keeps the pronunciation or spelling of the source cultural item intact, as one of the most common methods of foreignization and two foreignizing explanatory strategies suggested by Aixelá (1996: 
62): (a) extra-textual (footnote, endnote, glossary, commentary/translation in brackets, in italics, etc.), and (b) intra-textual (an explanation within the text) glosses.

\section{Translation strategies used when translating lexical Sovietisms-realia}

\subsection{Transliteration}

A transliteration, a transliteration combined with an intra-textual gloss, and an adaptation occur in the translations of the compound in the twenty-eighth chapter, in which Woland's servants Koroviev and Begemoth go to a "торгсин," a currency store, which offered a great variety of goods in exchange for foreign currency.

(1) торгсин

(a) Deleted

(b) Torgsin Store

(c) Torgsin Store

(d) a currency store

(Bulgakov 1966-1967/1988: 395)

(Ginsburg 1967)

(Glenny 2014: 391)

(Burgin and O’Connor 1995: 298)

(e) Torgsin foreign currency store

(Pevear and Volokhonsky 1997: 347)

(f) Torgsin

(Karpelson 2006: 354)

(Aplin 2008: 353)

In Ginsburg's translation based on a censored version the term is deleted. Otherwise, all translators except for Pevear and Volokhonsky opted for a transliteration with or without an intra-textual gloss, keeping the original name and preserving the foreign spirit, hence at the same time making the term clear to readers. Pevear and Volokhonsky's literal translation is also acceptable, though not consistent with the otherwise overall foreignizing strategy in their translations. Aplin's transliteration without a gloss is consistent with a foreignizing method but may cause problems for English-speaking readers. We find extra-textual glosses in Pevear and Volokhonsky's (1997: 412), Karpelson's (2006: 416) and Aplin's (2008: 410) translations, while in Ginsburg's translation the whole part of the text in which the term is used is deleted.

There are other examples in which the strategy of transliteration which keeps the cultural aspect intact is used consistently by all translators but Glenny. Thus, in the first chapter the poet Bezdomniy proclaims that Kant should be sent to Соловки (Bulgakov 1966-1967/1988: 10), a casual name for the Soviet work camps, the Solovetsky Special Purpose Camps, for his proofs of God's existence. There are many examples in the text where Soviet vocabulary is ascribed to characters coming from a mythological or a biblical context and not from a Soviet reality (Satan is often addressed with "citizen"; Satan's servant, a black cat named Behemoth, requires a "passport" from an official, etc.). Bulgakov's brilliant irony lends the text distinctive undertones and invites a number of interpretive options. The translator's task in such cases is a difficult one, as an English-speaking reader should understand the irony of the episode, which depends entirely on the fact that the Soviet language occurs in 
unusual verbal situations. In all translations but Glenny's we find the transliteration "Solovki" (Pevear and Volokhonsky 1997: 13; Ginsburg 2014: 10; Burgin and O’Connor 1995: 8; Karpelson 2006: 8; Aplin 2008: 11). Pevear and Volokhonsky (1997: 398), Burgin and O'Connor (1995: 339) and Aplin (2008: 405) also provide an extratextual gloss, which is a good choice, as the term is unfamiliar to English readers and they may face difficulties figuring out the meaning from the context.

It is only in Glenny's translation that we find a transliteration accompanied by the intra-textual gloss "Solovki asylum" (Glenny 2014: 19), which is problematic in terms of rendering the original meaning, as instead of a suggestion to send Kant to one of the Soviet regime's most horrible prisons, Glenny makes Bezdomniy suggest sending Kant to a mental hospital - a suggestion which changes the meaning completely. In the original, Bezdomniy does not perceive Kant as being a mentally disturbed person but a criminal who should be punished for questioning atheism, a foundation of the Soviet state. In this case, some kind of explanatory technique within the text is necessary to make sure that the meaning is rendered correctly. A more successful choice of an intra-textual gloss as combined with a transliteration would be "Solovki prison camp."

Transliteration with or without glosses also occurs when translating a drink, Абрау-Дюрсо, the famous Soviet champagne, rendered as "Abrau-Durso" in all translations but Glenny's, which uses a generalied adaptation "champagne bottle" (Glenny 2014: 242). In two translations, the term is incorrectly modified with "wine" (Ginsburg 1967: 230) and (Pevear and Volokhonsky 1997: 212) and only in one with “champagne" (Burgin and O'Conno 1995: 178). Burgin and O'Connor also offered an extra-textual gloss (1995: 344). The transliteration "Abrau-Durso" without glosses was used by Karpelson (2006: 166) and Aplin (2008: 215).

As the next example illustrates, a semi-transliteration does not always guarantee a successful rendering of a term. The Sovietism пилатчина, a contemptuous description of the Master's work by one of the critics, used by the Master who talks about negative reviews he was given by critics after the publication of his novel on Pontius Pilate, was equally transliterated by all translators as "pilatism" (Ginsburg 1967: 161; Glenny 2014: 167; Burgin and O'Connor 1995: 120; Pevear and Volokhonsky 1997: 144; Karpelson 2006: 111, and Aplin 2008: 144) but an extra-textual gloss can only be found in the Burgin and O'Connor translation (1995: 348) and in the Karpelson (2006: 311) translation. The problem is that an English-speaking reader is most likely unaware of the word-formation process in the Soviet Union whereby the suffix "chin" was usually attached to Sovietisms that described a negative, even an insulting, term. The English suffix "ism" (implying state, system of doctrines) does not illustrate the negative connotations attached to the original word, though these are crucial for illustrating how the Master's lifework was destroyed by the critics.

\subsection{Calques}

One would expect the use of calquing when translating compounds as this method, according to Newmark (1988: 84), is often used for translating common collocations, names of organizations and the components of compounds. Hence, the results of the analyzed examples show that, though the use of calques prevails, other translation strategies were also employed in a few cases. 
Translating by calques occurs consistently in all six translations in the cases of two compounds - "Госбанк", a state bank, is rendered by all translators as "a state bank” (Ginsburg 1967: 230; Glenny 2014: 209; Burgin and O’Connor 1995: 176; Pevear and Volokhonsky 1997: 209; Karpelson 2006: 166; and Aplin 2008: 211) and “Интурист," a foreign tourist, as a "foreign tourist" (Ginsburg 1967: 13; Glenny 2014: 16; Burgin and O’Connor 1995: 10; Pevear and Volokhonsky 1997: 15; Karpelson 2006: 9; and Aplin 2008: 13). Though both examples allow for relatively "unproblematic" calquing that is to a large extent familiar to readers, the connotative meaning of compounds as important lexical characteristics of the Soviet discourse is lost.

Other compounds are translated by different calques, such as жилплощадь, a living space, mentioned in the ninth chapter. Considering the permanent shortage of living space in the Soviet Union, a possibility to acquire а жилплощадь was one of the people's main concerns.

(2) жилплощадь

(a) dead man's rooms

(Bulgakov 1967/1988: 468)

(Ginsburg 1967: 102)

(b) housing space

(Glenny 2014: 112)

(c) housing space

(Burgin and O’Connor 1995: 72)

(d) living space

(Pevear and Volokhonsky 1997: 95)

(e) living space

(f) living space

(Karpelson 2006: 73)

(Aplin 2008: 94)

There is little difference between "housing space" and "living space," as both versions transfer the denotative meaning well. Ginsburg is the only translator who instead of a calque used a modulation, which is also acceptable, since it is clear from the context that Bulgakov is referring to the recently-deceased Professor Berlioz, who died at Patriarch's Ponds.

Similar tendencies of translating by different calques may also be noticed in the translation of the compound домоуправлении - a house committee that was entrusted with enormous power and responsible for the administration of anything to do with general issues affecting the building. Calquing transfers the meaning well but does not illustrate a degradation of Soviet Russian, namely, by reducing the language to blendings, compounds and clichés.

(3) домоуправлении

(a) house management

(Bulgakov 1966-1967/1988: 527)

(b) house management

(Ginsburg 1967: 180)

(c) house committee

(Glenny 2014: 140)

(d) house management

(Burgin and O'Connor 1995: 78)

(Pevear and Volokhonsky 1997: 160) 
(e) tenant board

(Karpelson 2006: 124)

(f) House Management Committee

(Aplin 2008: 121)

In my opinion calquing with the word "management" transfers the meaning accurately, evoking associations with property management, though this contemporary term is probably not the best option for transferring a distant Soviet discourse. "House committee" sounds more authentic. Karpelson used an adaptation which is culturally specific; coming from Canada, the translator probably had in mind the Landlord and Tenant Board (formerly the Ontario Rental Housing Tribunal). If this is the case, the question arises whether English-speaking readers from other countries would have the same immediate associations or whether the term may seem odd and out of place. Aplin's extended semi-calquing is transparent and allows for an easy interpretation.

Hence, there are also examples in which the use of calques is inconsistent. When translating the compound финдиректор, the head of the box, only four translators used calquing.

(4) [...] в кабинете у финдиректора [...]

(Bulgakov 1966-1967/1988: 476)

(a) [...] in financial manager's office [...]

(Ginsburg 1967: 88)

(b) $[\ldots]$ in the treasurer's office [...]

(Glenny 2014: 122)

(c) $[\ldots]$ in the financial director's office $[. .$.

(Burgin and O'Connor 1995: 67)

(d) $[\ldots]$ in the findirektor's office $[. .$.

(Pevear and Volokhonsky 1997: 92)

(e) $[\ldots]$ in the fin-director's office [...]

(Karpelson 2006: 80)

(f) $[\ldots]$ in the Financial Director's office [...]

(Aplin 2008: 103)

Only Glenny used a literal translation, whereas the others prioritized the form and content of the source text by employing foreignizing strategies of calquing and transliteration; only in Pevear and Volokhonsky's translation is this combined with an extra-textual gloss (1997: 403). The absence of a gloss in Karpelson's translation suggests that the translator assumed the Sovietism to be easy to decipher, as the word "director" means the same in English and in Russian and neither should the stem "fin" confuse readers. Both choices perfectly illustrate an important lexical characteristic of the Soviet language. The calques offered by the other translators transfer the meaning well but fail to re-create an effect of the source term. It is not clear why Aplin used capital letters, though it appears to be the translator's consistent strategy when translating Sovietisms.

Calques and semi-calques are also used by a few translators when rendering the term сверхмолния, super-lightning, an ironic rendering of the normal молния, meaning priority telegram. It is important not to lose the ironic connotations in the translation, as in this case Bulgakov makes fun of the exaggerations that add to the humour of accounts of Soviet life. In Soviet public discourse, the results were always 
"the best," the success "extraordinary," the people "the luckiest" and the courts "the fairest." The context is also important as the word is used several times in a passage in which one of the protagonists receives one "super-lightning" after another.

(5) Сверхмолния вам, распишитесь.

(a) Telegram. Sign for it.

(Bulgakov 1966-1967/1988: 478)

(Ginsburg 1967: 118)

(b) Priority telegram for you. Sign here.

(Glenny 2014: 124)

(c) Express telegram for you. Sign, please.

(Burgin and O'Connor 1995: 87)

(d) Take a super-lightning telegram.

(Pevear and Volokhonsky 1997: 107)

(e) Super-speed telegram for you. Sign here.

(Karpelson 2006: 121)

(f) Super-lightning for you. Signature.

(Aplin 2008: 122)

Since in a transliterated form the term is only meaningful to a Russian reader of the English translation, none of the translators decided for a transliteration, though Aplin strictly followed another foreignizing principle by using a calque without a gloss. It should not be too hard to understand the denotative meaning from the context, though the ironic connotations may remain unclear to readers. For this reason, Pevear and Volokhonsky used an intra-textual gloss, modifying a calque by the explanatory "telegram," which should suffice to illustrate the original's connotative meaning without an extra-textual gloss (1997: 404). Karpelson's deciding for a semi-calquing combined with an intra-textual gloss capably transfers the denotative meaning and the irony of the original, as "super-speed telegram" sounds odd and funny in English. Burgin and O'Connor, as well as Glenny, used adaptation, transferring the denotative meaning but losing the ironic connotations. Ginsburg's partly literal generalized translation deleted an important segment of the term, completely destroying the ironic effect of the text.

\subsection{Literal translation}

In the following case, all translators decided for a literal translation combined with an intra-textual gloss. In the first chapter Woland mentions to Professor Berlioz that his head will be cut off by а комсомолка, a female member of the Young Communist League.

(6) [...] русская женщина, комсомолка.

(Bulgakov 1966-1967/1988: 395)

(a) [...] a Russian woman, a member of the Young Communist League.

(Ginsburg 1967: 8)

(b) [...] a Russian woman, a member of the Komsomol.

(Glenny 2014: 22)

(c) [...] a Russian woman, a member of the Komsomol.

(Burgin and O'Connor 1995: 10)

(d) [...] a Russian woman, a Komsomol girl.

(Pevear and Volokhonsky 1997: 8) 
(e) [...] Russian woman, a member of the Komsomol.

(Karpelson 2006: 7)

(f) [...] a Russian woman in the Communist League of Youth.

(Aplin 2008: 10)

Surprisingly, neither of the translators decided for a transliteration which could have been combined with an intra-textual gloss. The extra-textual gloss is offered only in Pevear and Volokhonsky's translation (1997: 399). As the Sovietism Komsomol may easily be classified as an international term, Glenny, Burgin and O'Connor and Karpelson presumably considered it well-known to English readers, though in such cases it is always hard to evaluate readers' knowledge of the foreign discourse. Ginsburg and Aplin opted for clarifying intra-textual glosses which closely follow the source text in rendering the message but which are affected by the deforming tendencies of expansion.

Literal translation also occurs consistently in another example from the novel's sixth chapter. There a communal flat - a distinctive phenomenon of the early Soviet epoch, namely, a flat shared by several families who used the same kitchen and toilet facilities - is mentioned. One of the main attributes of a communal flat, having a "common kitchen" (a place shared by all the tenants of a communal flat), is referred to in a dialogue between two friends who are discussing Griboedov's House, where MASSOLIT's main office is based. There is a magnificent restaurant in the building which can only be visited by the members of MASSOLIT, a privileged group of proletarian writers who could enjoy a wide range of rare dishes that common Soviet people could not even dream about. While discussing various delicious courses served at Griboedov's, one of the friends, Amvrosiy, states that it is impossible to cook something as delicious as perch au naturel in an overcrowded communal flat kitchen where each family has just enough space for a small stove.

(7) Слуга покорный, - трубил Амвросий, - представляю себе твою жену, пытающуюся соорудить в кастрюльке в общей кухне дома порционные судачки аля натюрель.

(Bulgakov 1966-1967/1988: 434)

(a) 'Thanks a million,' boomed Amvrosy, 'I can imagine your wife trying to cook perch au naturel in a saucepan in the communal kitchen at home!'

(Ginsburg 1967: 62)

(b) 'Thank you very much,' trumpeted Ambrose. 'Just imagine your wife trying to cook filets de perche au naturel in a saucepan, in the kitchen you share with half a dozen other people!

(Glenny 2014: 71)

(c) "Thank you, no," trumpeted Amvrosy, "I can just imagine your wife, trying to cook perch au naturel in the frying pan of your communal kitchen!"

(Burgin and O'Connor 1995: 47)

(d) 'I humbly thank you,' trumpeted Amvrosy, 'but I can imagine your wife, in the communal kitchen at home, trying to do perch au naturel to order in a saucepan.'

(Pevear and Volokhonsky 1997: 70)

(e) I can imagine your wife, struggling with her tiny pot in the communal kitchen at home, trying to construct perch au naturel à la carte!

(Karpelson 2006: 68)

(f) I can imagine your wife attempting to construct portions of pikeperch au naturel in a little saucepan in the communal kitchen at home.

(Aplin 2008: 66) 
It should be noted that Bulgakov's ironic response to social inequality in Soviet society may easily be overlooked if the reader is unfamiliar with the conceptual meaning of the term "communal flat." Glenny's partly literal translation, combined with an intra-textual gloss, conveys the original meaning well. The use of the verb "to share" signifies that the place was used by several people and makes Amvrosy's statement about the impossibility of cooking in such conditions logical. The only problem with Glenny's translation is the number ("half a dozen people") as a communal kitchen may have been shared by up to ten families.

The literal translation "communal kitchen" used by the other translators, though rendering the original term correctly, does not explain much to a reader unfamiliar with the housing shortage in the Soviet Union. Only two translations, those of Pevear and Volokhonsky (1997: 64) and Burgin and O'Connor (1995: 342), offer an extratextual gloss on a "communal apartment." Another problem is the confusing use of the word "home" along with the adjective "communal" in the translations by Ginsburg, Pevear and Volokhonsky, Karpelson, and Aplin. In Russian, the word дом has a complex semantic structure, as it refers to both a fixed residence of family or household, expressed by the English word "home," and to a building for human habitation, expressed in English by the word "house." For Western readers "home" is associated with a private space and has a completely different connotative meaning than a building of communal flats for Russian readers. As a result, the expression "communal home" sounds almost like an oxymoron. The lack of a common connotative field may have been compensated with the word "house" instead.

An unnecessary structural change occurs in Burgin and O'Connor's translation, which adds the possessive pronoun "your" to "communal kitchen," as the expression "your communal flat" is affected by a similar connotative dissonance evident in the case of "a communal kitchen at home."

An interesting example of a cultural concept rendered differently by all translators occurs in the same passage. When describing the delicious dishes and drinks served at Griboedov's, Bulgakov mentions нарзан, a carbonated mineral water with therapeutic effects that was very popular in Soviet times.

(8) Шипящий в горле нарзан?!

(a) The sparkling Narzan?

(Bulgakov 1966-1967/1988: 434)

(b) And the sparkling wines!

(Glenny 2014: 71)

(c) The Narzan water fizzing in your throat?!

(Burgin and O'Connor 1995: 47)

(d) Cool seltzer fizzing in your throat?!

(Pevear and Volokhonsky 1997: 70)

(e) The fizzle of seltzer in your mouth!

(Karpelson 2006: 68)

(f) The Narzan that fizzed in your throat?!

(Aplin 2008: 66)

Unfortunately, Glenny apparently did not use a dictionary and he mistranslated the term, while Pevear and Volokhonsky, surprisingly, decided in favour of a generalized adaptation, replacing an unfamiliar term with a more general equivalent familiar to target readers (whereas in most other cases they strived to keep as many 
foreign elements in the translation as possible). The same translation strategy may also be observed in Karpelson's translation, which is closer to the original, as Bulgakov does not use the modifying adjective "cool" introduced in Pevear and Volokhonsky's version for some unknown reason. Ginsburg, Aplin, and Burgin and O'Connor transferred the term by using a transliteration, which signals adhering to the foreignizing principle of translation. Ginsburg used an intra-textual gloss in the form of the adjective "sparkling," deleting the rest of the context. Burgin and O'Connor used a transliteration combined with an intra-textual gloss, though "Narzan mineral water" would be more accurate. In this case the reader should not face major difficulties when confronted with a foreign element, as it is clear from the context that "Narzan" is a drink.

Literal translation also occurs in the fifth chapter, when Woland's servant Behemoth accuses Stepa Likhodeev, a director of the Variety theatre, of using his казенную машину, an official car with a driver, which was usually given to highly positioned functionaries.

(9) Машину зря гоняет казенную!

(Bulgakov 1966-1967/1988: 458)

(a) Using the government car for nothing.

(Ginsburg 1967: 92)

(b) Drives around in a free car!

(Glenny 2014: 100)

(c) And he runs the official car ragged!

(Burgin and O'Connor 1995: 69)

(d) Availing himself of a government car.

(Pevear and Volokhonsky 1997: 96)

(e) Abusing the company car.

(Karpelson 2006: 64)

(f) He misuses an official car.

(Aplin 2008: 83)

While other translators used literal translation, which functions well because the term should also be familiar to Western readers, Glenny mistranslated the term, losing an important connotation: the implication that Stepa enjoyed privileges the majority of the Soviet people did not have.

The final example is the problematic omission of the official form of address which occurs in the translations of “Товарищ дежурный," a comrade dispatcher.

(10) Милиция? Товарищ, дежурный [...]

(Bulgakov 1966-1967/1988: 446)

(a) Militia? Comrade officer [...]

(Ginsburg 1967: 77)

(b) Now look, everybody [...]

(Glenny 2014: 84)

(c) Is this the police? Comrade dispatcher [...]

(Burgin and O'Connor 1995: 58)

(d) Police? Comrade officer-on-duty [...]

(Pevear and Volokhonsky 1997: 70)

(e) Police? Whoever's on duty [...]

(Karpelson 2006: 52)

(f) Is that the police? Comrade duty officer [...]

(Aplin 2008: 69) 
The omission of "comrade" in Glenny's and Karpelson's translations means a loss of one of the most significant features of the Soviet speech. Consequently, both translators fail to re-create the official register, as it is also hard to imagine a Soviet citizen calling a police officer and not using the official form of address. Although the other literal translations transfer the meaning well, Burgin and O'Connor's version is perhaps the most successful because it captures the fact that this is a phone conversation. It should be noted that Ginsburg is the only translator who decided to transliterate the term “милиция," militia.

\section{Translation strategies used when translating semantic Sovietisms-realia}

Semantic Sovietisms are not as common in the narrative as lexical ones, though one of the most interesting examples refers to an important attribute of a communal flat. This is mentioned in the second part of the novel, in which Bulgakov introduces Margarita, who lives with her husband in a large apartment with a great deal of privacy - a true luxury in Stalinist Moscow. However, in spite of material well-being, Margarita is unhappy without her lover, the Master. In a short passage which is crucial for understanding Margarita's character and the motives for her further actions, Bulgakov explains that Margarita was never forced to face the challenges of living in a communal flat (a struggle many women living in the Soviet Union faced every day) by stating that she never had to touch а примус, a little one-burner kerosene (paraffin) stove. Though the word existed before, it was in Soviet times that it acquired a new semantic sense and became one of the most significant features associated with the tiny kitchen of a communal flat.

(11) Маргарита Николаевна никогда не прикасалась к примусу.

(Bulgakov 1966-1967/1988: 584)

(a) Margarita Nikolayevna never touched a primus stove.

(Ginsburg 1967: 236)

(b) Margarita never had to cook.

(Glenny 2014: 249)

(c) Margarita Nikolaevna never touched a primus stove.

(Burgin and O'Connor 1995: 186)

(d) Margarita Nikolaevna had never touched a primus stove.

(Pevear and Volokhonsky 1997: 217)

(e) Margarita Nikolaevna never touched a primus burner.

(Karpelson 2006: 221)

(f) Margarita Nikolaevna never touched a Primus.

(Aplin 2008: 222)

All translators but Glenny rendered the term by implying a familiar strategy of a transliteration combined with an intra-textual gloss. Glenny's choice of a transposition (a shift of a grammatical category, namely of a class), replacing a noun with the verb "to cook," also transfers the meaning well; hence, a transposition does not help to solve the problem of deleting a foreign cultural context, a common strategy in Glenny's translation. Ginsburg, Burgin and O'Connor, and Pevear and Volokhonsky used the noun "stove," while Karpelson modified the Sovietism by using "burner," which has multiple meanings and is less successful because the original term "primus" was used only for cooking and never for heating or any other purpose. Pevear and Volokhonsky also provided an extensive extra-textual gloss earlier in the text 
(64), and Aplin's transliteration strictly follows the principle of foreignization (though the use of a capital letter is rather confusing since it implies that "Primus" may be a personal name, a location or a brand name).

In Bulgakov's works we often find a discrepancy between the traditional semantics of a word used before the revolution and "the semantics of a new prevailing linguistic model" (Verch 2010: 138-139) acquired through propagandistic Soviet rhetoric. To be able to recognize Bulgakov's "double talk," the reader should be familiar with both meanings. An interesting example occurs in the part when Ivan Bezdomniy, who has just witnessed the death of his friend Professor Berlioz, unsuccessfully chases Satan through the labyrinth of Moscow's streets. After appearing in Griboedov's restaurant, wearing only underwear and holding a candle in his hand, Bezdomniy is put in a mental hospital. Ivan is certain that he has been falsely diagnosed as insane and offends his friend Riukhin, who brought him to the mental hospital, by using another typically Soviet term, кулачок, a derogatory diminutive term in the Soviet discourse used for a prosperous peasant liquidated in the 1930s, a semantic Sovietism which acquired the function of a swearword in Stalin's era. Though all translators used the transliteration "kulak," in this case (Ginsburg 1967: 75; Glenny 2014: 84; Burgin and O’Connor 1995: 56; Pevear and Volokhonsky 1997: 81; Karpelson 2006: 67; Aplin 2008: 89), we find an extra-textual gloss only in Pevear and Volokhonsky's (1997: 403) and Burgin and O'Connor's (1995: 344) translations. It is hard to expect the western reader to be familiar with the nuances of the term "kulak." In this context, it is used as an insult, whereas in pre-revolutionary speech "kulak" designated a wealthy and prosperous farmer. In Soviet colloquial discourse, meanwhile, "kulak" acquired the new sense of "an enemy." It is difficult to understand without additional comments that Bulgakov ironically refers to a brainwashing system introduced in the Soviet state, one that resulted in distortions of words' meanings and thus in the deformation of the Russian language. Ivan does not realize that the word "kulak" used to have a positive meaning because he remembers it only from propagandistic slogans. As in the previous case, the translation should illustrate Ivan's intention to offend his friend by questioning his proletarian identity and by using a word with distinctly negative connotations. Another problem not addressed equally by the translators is the derivative diminutive form "кулачок" (Bulgakov 19661967/1988: 444) used in the second part of Ivan's statement, which brings with it a very clear derogatory meaning that needs to be reflected. Pevear and Volokhonsky, as well as Ginsburg, indicated the diminutive form with the modifying adjectives "little," (1997: 75) and Aplin with "petty," (2008: 89) while other translators ignored this problem.

A similar example occurs in a dialogue between Ivan Bezdomniy and Doctor Stravinsky in a mental hospital. The outraged Ivan addresses his doctor as вредитель, an agricultural pest. In the Soviet discourse the word had acquired the additional meaning of a political saboteur and was usually applied to a counter-revolutionary, someone who intentionally vandalized state property, a crime specified in the criminal code of the Soviet Union in the Stalinist era. As with other cases of Sovietisms, the epithet does not function if it is translated directly and without an explanation. In the original the term illustrates not merely Ivan's intention to offend the doctor, but it may also be interpreted as a serious accusation. Thus, if we interpret the word as being part of Soviet vocabulary, Ivan's rhetoric is extremely offensive. 
(12) Здорово, вредитель! [...]

(a) "Hello, saboteur," [...]

(Bulgakov 1966-1967/1988: 443)

(b) 'Hello, you quack!' [...]

(Ginsburg 1967: 74)

(Glenny 2014: 83)

(c) Hello, you wrecker!" [...]

(Burgin and O'Connor 1995: 56)

(d) 'Greetings, saboteur!' [...]

(Pevear and Volokhonsky 1997: 64)

(e) "Greetings, wrecker!" [...]

(Karpelson 2006: 60)

(f) "Hi there, wrecker!" [...]

(Aplin 2008: 66)

Clearly, we cannot consider Glenny's version to be a successful translation. It can hardly be classified even as an adaptation, since it completely fails to communicate the same message or to evoke the same associations as the original. Merriam-Webster defines "quack" as "a pretender to medical skill: an ignorant or dishonest practitioner" but in the original, Ivan is not questioning the doctor's professional ability but his political beliefs. In this case, Glenny handles the Sovietism inattentively and disregards its stylistic coloration. The other translations used adaptations which function well in the context. Both "wrecker" and "saboteur" are close to the original term and illustrate Ivan's intention to insult and perhaps even to frighten the doctor. Pevear and Volokhonsky's (1997: 402) and Burgin and O'Connor's (1995: 343) translations also offer an extra-textual gloss in the comments.

A literal translation would be the best choice in the case of translating the semantic Sovietism гражданин, citizen. The term was used in the prerevolutionary discourse, yet later it acquired a meaning of a typical Soviet addressing for both genders. It is mentioned for the first time in the beginning of the first chapter when двое граждан, two citizens, appear at Patriarch's Ponds. Bulgakov introduces Soviet Moscow as the setting of the novel not only by mentioning a famous location (Patriarch's Ponds) but also by using a familiar addressing.

(13) двое граждан

(Bulgakov 1966-1967/1988: 386)

(a) two citizens

(Ginsburg 1967: 3)

(b) two men

(Glenny 2014: 13)

(c) two men

(d) two citizens

(Burgin and O’Connor 1995: 3)

(Pevear and Volokhonsky 1997: 7)

(e) two gentlemen

(Karpelson 2006: 4)

(f) two citizens

(Aplin 2008: 4)

It is unclear why only Ginsburg, Pevear and Volokhonsky and Aplin opted for a literal translation which functions perfectly well, as it is clear from the context who 
the "two citizens" are. Glenny's and Burgin and O'Connor's generalized adaptation makes a familiar setting more elusive. The inconsistency in Burgin and O'Connor's translation is even more surprising, as the next example illustrates that the translators used a literal translation when translating the same term in the fifth chapter. Karpelson's adaptation, which is a clear example of a domestication taken from an entirely different cultural context, is even less successful; it is also one of the very few examples in this translation of employing domesticating strategies.

In the fifth chapter, when Woland and his assistants produce a black-magic show, performing various tricks that reveal Muscovites' vanity and greed, the plural form граждане Bulgakov 1966-1967/1988: 496), citizens, is used. This time Ginsburg, Burgin and O'Connor, Pevear and Volokhonsky, and Aplin opted for the literal translation “citizens" (Ginsburg 1967: 129; Burgin and O’Connor 1995: 103; Pevear and Volokhonsky 1997: 125 and Aplin 2008: 125), while Karpelson and Glenny substituted the term with the adaptation "ladies and gentlemen" (Glenny 2014: 142 and Karpelson 2006: 95), completely destroying the humorous effect of using "citizen" twice in the original when addressing both genders.

\section{Conclusion}

Though the analysis here focused on merely a few of the most illustrative examples of translating Sovietisms in Bulgakov's narrative, it allows for an adequate assessment of the domesticating and foreignizing strategies used by the translators. The results demonstrated that all translators used similar foreignizing strategies: (a) transliteration, (b) semi-calque, (c) calque, (d) intra-textual gloss, (e) extra-textual gloss, and (f) literal translation, while domestication was achieved mainly through adaptation and, in two cases, through modulation and transposition. Glenny's version minimizes the foreignness of Bulgakov's narrative to a greater extent than other translations, offering fluent, undisturbed reading for English-speaking audience, albeit while almost completely erasing the foreign "spirit."

The comparative analysis also showed that the prevalence of domesticating principles does not depend on when a translation was published, as Ginsburg's translation was made in the same year as Glenny's, yet shows less tendencies towards domesticating strategies. The same is true for the more contemporary translations by Burgin and O'Connor, Pevear and Volokhonsky, Karpelson, and Aplin.

The denotative meaning is usually transferred well in all translations, though Glenny's version demonstrates more contextual deviances from the original than the other translations do. In most cases, connotative meanings are partly preserved through the use of foreignizing strategies or intra- and extra-textual glosses which proved to be sufficient to give readers adequate information without completely deleting Sovietisms.

If discussing translations of Bulgakov's work in the context of the prevalence of foreignizing/domesticating tendencies, an interesting conclusion offers itself. In spite of Venuti's statement that contemporary translators tend to translate fluently into English in order to produce an idiomatic and readable TT and thereby to create the illusion of transparency, the inclusion of foreignizing elements illustrates how Ginsburg and the contemporary translators Burgin and O'Connor, Pevear and Volokhonsky, Karpelson, and Aplin partly foreignize the translation and thus high- 
light the foreign nature of the source text. This makes the translated text a "site where a different culture emerges, where the reader gets a glimpse of a cultural other" (Venuti, 1995: 306).

Because Burgin and O'Connor's, Pevear and Volokhonsky's, Karpelson's, and Aplin's translations use foreignizing elements more or less consistently, the difference is then in the use of intra- and extra-textual glosses. Here, the question of subjectivity in evaluating the background of the readership and defining the criteria of "unfamiliar" arises. Apparently, Burgin and O' Connor considered their target readers' knowledge about the Soviet culture insufficient, as, out of two hundred and nine extensive comments, eighteen Sovietisms are explained. Pevear and Volokhonsky's translation is even more "scholarly" and in a way patronizing. It includes one hundred and seventy-five comments, with twenty-seven Sovietisms explained. The primary difference between Burgin and O'Connor's and Pevear and Volokhonsky's translations is in the length of the extra-textual glosses and the choice of which Sovietisms to explain. Apparently, Burgin and O'Connor's translation, the first to be equipped with comments, influenced later translators, who considered this strategy successful.

Considering the overall tendency to "fluency" highlighted by Venuti, more contemporary translations by Karpelson, and, particularly, Aplin, surprisingly, show even more tendencies to foreignizing principles. Transliterations, calques and literal translation occur in almost the same examples as in Pevear and Volokhonsky's translation, as well as in Burgin and O'Connor's translation, though these instances are seldom combined with intra-textual glosses. Karpelson's thirty-seven glosses include only three explanations of Sovietisms, and Aplin's one hundred and thirty-one glosses explain a mere seven Sovietisms. It is also not always clear which selection criteria Karpelson and Aplin used, as, for instance, most Sovietisms which would normally require explanations were not included in the comments - unlike personal and biblical names which the translator apparently considered unfamiliar. To avoid criticism on the incompleteness of the comments, Karpelson states that,

These notes provide background for some of the characters, locations, and events in The Master and Margarita. It is beyond the scope of this document to explain all of Bulgakov's numerous references and sources, particularly those that can be found easily in an encyclopedia (2006: 402).

Re-translations offer a unique opportunity for scholars to follow translating tendencies over time. As is evident from the analysis, all translators of Bulgakov's work with the exception of Glenny successfully employed foreignizing elements, avoiding an overall domestication of the original. Even though it was impossible, due to the number of the case texts, to assess all examples in the current study, the tendencies were made clear. Contemporary translators successfully use foreignized translation strategies, conveying, if not emphasizing, the 'otherness' of the original. Thus, the statement that the contemporary western translation process shows a greater prevalence for domestication seems too broad to be applied to all cases as each translation should be evaluated as an individual and unique act of a cultural transference. 


\section{NOTES}

1. Bulgakov, Mikhail (1967): The Master and Margarita. (Translated from Russian to English by Mirra Ginsburg). Grove Press: New York.

2. Bulgakov, Mikhail (2014): The Master and Margarita. (Translated Russian to English by Michael Glenny, first translated from Russian to English in 1967). London: Vintage.

3. Bulga kov, Mikhail (1995): The Master and Margarita. (Translated Russian to English by Dianna Burgin and Katherine Tiernan O'Connor). New York: Random House Vintage.

4. Bulgakov, Mikhail (1997): The Master and Margarita. (Translated from Russian to English by Richard Pevear and Larisa Volokhonsky). London: Penguin Books.

5. Bulgakov, Mikhail (2006): The Master and Margarita. (Translated from Russian to English by Michael Karpelson). New York: Lulu Press.

6. Bulgakov, Mikhail (2008): The Master and Margarita. (Translated from Russian to English by Hugh Aplin). London: Oneworld Classics.

7. Реалии - это слова и словосочетания, называющие предметы, явления, объекты, характерные для жизни, быта, культуры, социального развития одного народа и малознакомые либо чуждые другому народу, выражающие национальный и (или) временной колорит.

8. Лексические знаки эпохи.

9. Таким образом, в дополнение к коннотативному значению, к национальному колориту обычных реалий, советизмы обладают своим, специфическим только для советского строя социальным колоритом [...]

10. Трехступенчатая, так сказать, коннотация (национальный, исторический и социальный колорит).

11. [...] вне нашего лагеря.

12. Собственно советизмы- реалии, характерные для Советского Союза (совхоз, неотложка, ЖЭК, иелинник, стахановеи), - переводят, обязательно учитывая отсутствие их референтов в стране читателя перевода, не упуская тем не менее из виду то общее положение, что читатель из социалистической страны в любом случае обладает более обширными фоновыми знаниями об СССР по сравнению с читателями из капиталистических стран. Региональные советизмы, которые для любой социалистической страны чаще всего мало чем отличаются по существу от национальных, переводятся на языки стран социализма принятыми там эквивалентами, обычно транскрипциями или кальками.

Интернациональные советизмы такие, как Совет, спутник, больщевик, настолько широко известны, что их не нужно особо оговаривать и объяснять; достаточно бывает обычной транскрипции.

13. Лексические: слова, актуализировавшиеся, появившиеся или образованные в 20-70-е годы и обозначавшие явления советской действительности.

Семантические: новые значения старых слов, появившиеся или актуализировавшиеся в советское время.

Коннотативные: оттенки значения, появившиеся в 20-70-е годы.

14. Наблюдается следующая закономерность: в текстах, рассчитанных на специалистов, на читателей, знакомых с советскими реалиями, преобладают такие способы передачи «советизмов», как транслитерация и калька (например, агитпункт - agitpunkt, дружинники - dru-zhinniki, область - oblast, товарищеский суд - comradely court), тогда как в текстах, адресованных более широкой аудитории, чаще встречаются объяснительный, описательный и другие виды перевода (например, агитпункт - voter education centre, дружинники - volunteer patrols, товарищеский суд - citizen court), а транслитерация н калька обычно сопровождаются пояснительным комментарием.

15. [...] словом или сочетанием с нулевой коннотацией.

\section{REFERENCES}

Aixelá, Javier Franco (1996): Culture-specific items in translation. In: Roman Alvarez and Maria Carmen-Africa VIDAL, eds. Translation, power, subversion. Clevedon: Multilingual Matters: 52-78.

Andrews, Adna and Maksimova, Elena A. (2010): Russian Translation. Theory and Practice. London and New York: Routledge.

BAKer, Mona. (1992): In Other Words: A Course Book on Translation. London: Routledge. 
Bellos, David (2011): Is That a Fish in Your Ear? Translation and the Meaning of Everything. New York: Faber and Faber.

CATford, John (1965): A Linguistic Theory of Translation. London: Oxford University Press.

Chesterman, Andrew. (1997). Memes of Translation: The Spread of Ideas in Translation Theory. Amsterdam \& Philadelphia: John Benjamins.

Eco, Umberto (2001): Experiences in Translation. (Translated from Italian to English by Alastair Mcewen) Toronto: University of Toronto Press.

Hervey, Sandor And Higgins, Ian (2002): Thinking French Translation. A Course in Translation Method: French to English. London: Routledge.

Lederer, Marianne (2003): Translation: The Interpretive Model. (Translated from French to English by Ninon Larché). Manchester; Northampton, MA: St. Jerome Pub.

Newmark, Peter (1981): Approaches to Translation. Oxford \& New York: Pergamon.

Nord, Christiane (2005). Text Analysis in Translation. Amsterdam: Rodopi.

OitTinen, Riitta (2006): No innocent act: On the ethics of translating for children. In: Jan VAN Coillie and W.P. Verschueuren, eds., Children's Literature in Translations: Challenges and Strategies. Manchester/Kinderhook: St. Jerome, 35-46.

Piknurova, Anna (2005): Судьба совьетизмов в русском языке конца XX - начала XXI веков на материале словарей и текстов. (Sud'ba sovetizmov v russkom yazyke kontsa XX nacha-la XXI vekov (na materiale slovarey i tekstov)). [Sovietisms fate in Russian late $\mathrm{XX}^{\text {th }}$ - early XXI ${ }^{\text {th }}$ century (based on dictionaries and texts)]. Doctoral thesis, unpublished. University of Saratov: Saratov.

Shveitser, Aleksander (1973): Перевод и лингвистика. (Perevod i Lingvistika). [Translation and linguistics]. Moscow: Voenizdat.

Van Leuven-Zwart, Kitty (1989): Translation and Original: Similarities and Dissimilarities, In: Target 1/2:151-181.

Venuti, Lawrence (1995): The Translator's Invisibility: A History of Translation. London: Routledge.

Venuti, Lawrence (2006): Translation as Cultural Politics: Regimes of Domestication in English. In: Daniel Weissbort and Astradur Eysteinsson, eds. Translation Theory and Practice: A Historical Reader. Oxford: Oxford University Press.

VERCH, Ivan (2010): Razumevanje jezikov književnosti. [Understanding Languages of Literature]. Ljubljana: Založba ZRC.

Vinay, Jean-Paul and Darbelnet, Jean (1958/1989): Translation Procedures (translated from French to English by Andrew Chesterman). In: Andrew Chesterman, ed. Readings in Translation Theory, Helsinki: Oy Finn Lectura, 61-69.

Vlakhov, Sergej and Florin, Sidor (1980): Непереводимое в переводе. (Neperevodimoe v perevode). [The Untranslatable in translation]. Moscow: Mezhdunarodnye otnoshenia.

Webster, Merriem: Dictionary and Thesaurus. https:/www.merriam-webster.com/

YANG, Wenfen (2010): Brief Study on Domestication and Foreignization. In: Translation. Journal of Language Teaching and Research 1 (1):77-80. 